\title{
An epidemiological study of cataracts in seawater farmed Atlantic salmon Salmo salar
}

\author{
Cecilie Ersdal $^{1, *}$, Paul J. Midtlyng ${ }^{2}$, Jorun Jarp ${ }^{1, * *}$ \\ ${ }^{1}$ National Veterinary Institute, PO Box 8156 Dep., 0033 Oslo, Norway \\ ${ }^{2}$ VESO, PO Box 8109 Dep., 0032 Oslo, Norway
}

\begin{abstract}
Cataracts in farmed Atlantic salmon have been known for many years, but the aetiology and importance of the disease have not been clarified. A cross-sectional field study of 51 cages of Atlantic salmon at 49 randomly selected sea sites was performed during the summer of 1998. The target population was spring and autumn entry groups of the 1997 generation salmon. Approximately 15 fish from each cage, altogether 777 fish, were autopsied by the same person. Each eye of the fish was scored for cataracts on a scale from 0 to 4 using an otoscope lamp with magnification. The weight and length of each fish were measured. The prevalence of cataracts was $83 \%$ and $79 \%$ in spring entry groups and autumn entry groups, respectively. The overall mean cataract index (mean score of both eyes) was 1.23 , being significantly higher in the spring entry groups (1.36) than the autumn entry groups $(0.85)$. The final results in the spring entry groups showed that the fish groups with higher weight at sea transfer also had a higher cataract index at inspection. The risk of development of cataracts varied significantly among the offspring from the 5 strains represented in the study. Fish from sites located in 2 counties in the southern part of Norway had a significantly higher cataract index than fish farmed in the northernmost county in the study. For the autumn entry groups none of the explanatory variables was significant. In the spring entry groups a significant negative relationship was observed between the cataract score and the weight of the fish at the time of inspection (Pearson's $r=-0.17$ ), while the corresponding correlation for the autumn released groups was $\mathrm{r}=$ -0.10 . Among the spring entry groups the average weight of the fish with the highest cataract score was estimated to about a third of the weight of the fish with no visible cataracts.
\end{abstract}

KEY WORDS: Cataracts · Epidemiology $\cdot$ Atlantic salmon $\cdot$ Risk factors Resale or republication not permitted without written consent of the publisher

\section{INTRODUCTION}

Cataracts are opacities in the eye lens or the lens capsule that mediate an abnormal dispersion of light through the lens and hence cause reduced visual ability and, ultimately, blindness. The opacities result from a disruption of the normal arrangement of the lens fibres or from alterations in the conformation or water-binding capacity of the proteins of the lens (Benedek 1997). As in other species, the fish lens can

\footnotetext{
*Present address: Norwegian School of Veterinary Science, PO Box 8146 Dep., 0033 Oslo, Norway

${ }^{* *}$ Corresponding author. E-mail: jorun.jarp@vetinst.no
}

be differentiated into nucleus, perinucleus, cortical zone and lens capsule. In farmed Atlantic salmon, cataracts are often localised in the cortex, but extensive cataracts may also affect the nucleus (Bjerkås et al. 1996, Wall 1998). The majority of cataracts reported in fish are considered irreversible, but osmotic cataracts and cataracts caused by water temperature fluctuations have been reported to be reversible (Hargis 1991).

Cataracts may be induced by a variety of noxious factors of a nutritional, environmental, chemical or infectious nature (Phelps Brown \& Bron 1996). In salmonids several causes have been proposed for the development of cataracts, many of them nutritional: 
(1) zinc deficiency (Ketola 1979, Barash et al. 1982, Richardson et al. 1985), (2) riboflavin deficiency (Poston et al. 1977, Hughes et al. 1981, Barash et al. 1982), (3) tryptophan deficiency (Poston \& Rumsey 1983), (4) thiamine deficiency (Hughes 1985) and (5) methionine deficiency (Poston et al. 1977, Barash et al. 1982, Walton et al. 1982, Cowey et al. 1992). Other factors associated with cataract formation are rapid fluctuations in water temperature (Loewenstein \& Bettelheim 1979, Bruno \& Raynard 1994, Bjerkås \& Bjørnestad 1999), rapid growth (Kincaid \& Elrod 1991, Bjerkås et al. 1996), fluctuations in the water salinity (Hargis 1991), triploid genetic constitution (Wall \& Richards 1992), genetic identity (strain) (Kincaid \& Elrod 1991), UV radiation (Cullen et al. 1993), cholinesterase inhibitors (Fraser et al. 1989) and electrolytic imbalance (Iwata et al. 1987).

Cataracts in seawater farmed salmon have been noticed for many years, but the incidence apparently increased in the 1990s. On the basis of a series of clinical investigations, Wall (1998) found a prevalence of cataracts ranging from 50 to $90 \%$ in Irish salmon farms in 1995 and 1996. Similar clinical findings were seen in Scotland during 1996. He reported a prevalence of cataracts varying from 5 to $90 \%$ in Norwegian seawater farms investigated during 1997. The cataracts developed around the time of smoltification in both freshwater and seawater reared fish (Wall 1998). In some sites a high number of fish showed marked lens opacities and those most affected appeared completely blind. In these sea sites, farmers reported a remarkable reduction in food consumption starting 3 to 4 wk before the signs developed. Vision is important for feed intake, and others (Page 1978, Bjerkås et al. 1996) have found an association between irreversible cataracts and reduced growth rate in farmed fish. Therefore, cataracts may have a potentially negative economical impact on salmonid aquaculture, and the ethical and animal welfare aspects of producing salmon with reduced eyesight are obvious.

The aims of the present field study of farmed Atlantic salmon transferred to seawater in 1997 were to (1) estimate the prevalence of cataracts, (2) analyse the association between some potential risk factors and the development of cataracts, and (3) analyse the relation between cataracts and the specific growth rate (SGR).

\section{MATERIALS AND METHODS}

Design and farm selection. A cross-sectional design was applied for the study. The target population was the Atlantic salmon smolts, fish transferred to sea during 1997. Groups transferred to sea between 1 March and 31 July 1997 were designated as spring entry groups, and groups transferred to sea between 1 September and 31 December 1997 were designated as autumn entry groups. Approximately 50 spring and autumn entry groups were selected in a proportion of $3: 1$, respectively. The study area was confined to the business area of 22 veterinary fish health services, which covers the coastline of Norway from the county of Rogaland in the south to the Troms county in the north (Fig. 1). Sea sites were selected proportionally to the number of sea sites in the various business areas and by a systematic random selection among 2 lists of sea sites in each area, 1 list covering spring entry sites and 1 covering autumn entry sites. A pool of substitutes was also generated in the same way.

Field work and questionnaire. The field work was carried out from 15 June to 2 September 1998. At each site, a net pen was chosen randomly among all pens containing either spring or autumn entry groups. Individual fish were captured by netting with a big catch net after crowding, a large landing net that was lowered in the middle of the cage or a hand net during feeding. The first 2 methods were preferred and were used for more than $50 \%$ of the net pens investigated. At least 15 fish from each cage were sampled and immediately subjected to eye examination, which was performed by the same investigator in all 49 sea sites visited. Before bleeding the fish were stunned by a blow to the head (41 sites) or anaesthetised with ben-

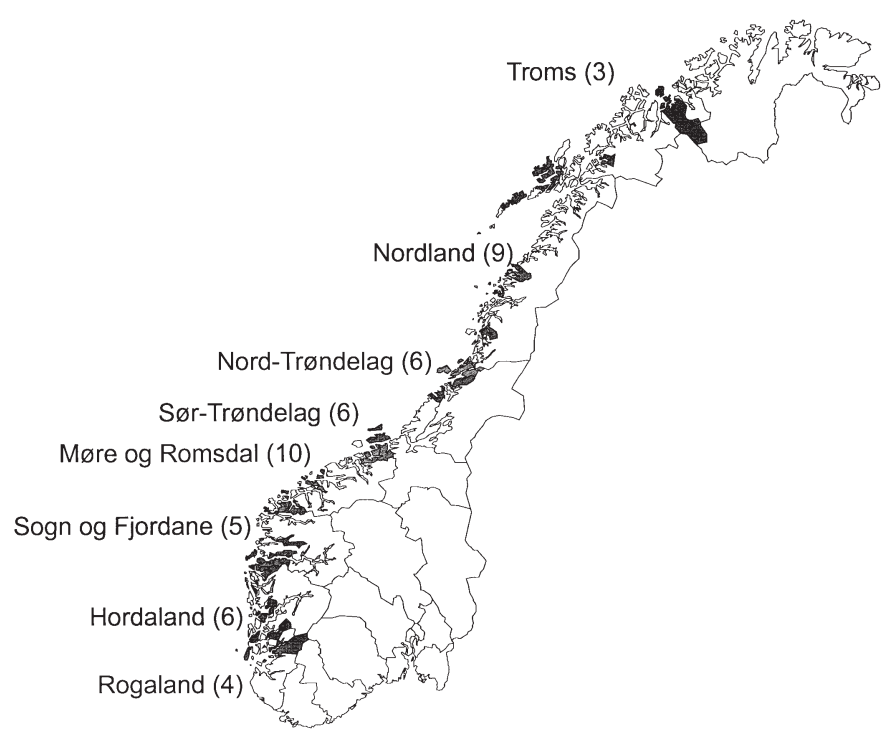

Fig. 1. Map of Norway showing the geographic distribution of the included seawater sites. The number of sites on county level is given in parentheses and the shaded areas within county show the municipalities represented 
zocaine (8 sites). The fish were then placed in a tub of seawater, and each fish was examined for the presence of cataracts in a dark room (machine room, feed store) using a focal light source (otoscope lamp with magnification). The fish were held by an assistant during the eye examination to prevent corneal damage. Each eye was scored on a scale from 0 to 4 where score 0 represented no visible opacity and score 4 represented opacity of more than $75 \%$ of the cross-sectional area of the lens (complete cataract) (Wall \& Bjerkås 1999). The location of the opacities in the lens was recorded and, thereafter, the fish were weighed and the fork length measured.

By interviewing the fish farmer and the local veterinarian, retrospective information on the fish sampled such as strain, egg supplier(s), smolt supplier(s), data on vaccination and sea transfer, diseases, monthly death rates, medical treatments, feed supplier, feed formula and feeding routines employed during the sea water production were collected. Any history of infectious pancreatic necrosis outbreaks indicating chronic damage to exocrine pancreas and thus potentially affecting uptake of nutrients from the feed was specifically recorded.

Data processing and statistical analyses. The statistical analyses were performed in SAS-PC System version 6.12 for Windows (SAS Institute Inc., Cary, NC, 1996).

The statistical analyses were performed separately on the spring and autumn entry populations because they were considered heterogeneous. For each fish examined, the cataract index, the mean cataract score of both eyes, was calculated. A general linear mixed model analysis using the individual fish as the statistical unit and the cataract index as the outcome variable was performed in PROC MIXED. This is a procedure based on maximum-likelihood estimation, and the likelihood-ratio statistic was used for comparison of the various models. The assumption of normality of the outcome was assessed by visual evaluation of the stem-and-leaf plots and normal probability plots. The modelling was manually conducted and a term for the site effect was forced into all models as a random effect in order to adjust for the cluster effect between individual fish coming from the same site, and thereby correcting the variance of the parameter estimates. As all the explanatory variables were registered at smolt group level, they were used as fixed effects in the model. In the analyses the continuously distributed variables; the weight of fish at vaccination and sea transfer, and the duration of the seawater period were categorised using 3 categories with cutoff at the $33 \%$ percentiles. The categorical variables considered were feed producer (4 levels), strain (5 levels) and geographic location (8 county levels). Ini- tially, the association between the various independent variables and the cataract index was analysed. Then all factors with likelihood-ratio statistic $\mathrm{p}<0.2$ were further included in a multivariate model, which subsequently was reduced until arrival at the final model. The elimination criterion was the type-III $F$ test, a p-value of 0.05 being used as the level for exclusion from the model. Some of the independent variables were correlated, but the estimated Pearson's correlation coefficient was $<0.7$ between all pairs of tested variables.

The SGR, percentage growth $\mathrm{d}^{-1}$ from the day of seawater transfer to the day of inspection, was calculated for each group using the equation [(mean value of the fish-level weight for all in each group/mean grouplevel weight at sea transfer $\left.)^{1 / \text { days in seawater }}-1\right] \times 100$. The Pearson correlation coefficient was used to analyse the relation between the mean group-level cataract index and the SGR for the group.

\section{RESULTS}

\section{Descriptive statistics}

Altogether 777 fish from 51 fish groups, situated in 49 sea sites were included in the study sample. The geographical locations of the sites are shown in Fig. 1. Few autumn entry groups were recruited from the northern part of Norway (Table 1), corresponding to the production patterns in this region, where sea transfer in autumn is less common than in the south. In total, 577 fish were sampled from 38 spring entry groups, and 200 fish were sampled from 13 autumn entry groups. All the spring entry groups except 1 consisted of $1 \mathrm{yr}$ old (S1) smolts, whereas there were three $1 \frac{1}{2} \mathrm{yr}$ old $\left(\mathrm{S}^{1} \frac{1}{2}\right)$ and ten 6 mo old smolts $\left(\mathrm{S}^{1} \frac{1}{2}\right)$ among the autumn entry fish.

The fish originated from 15 egg suppliers and had been raised in 46 different smolt production units. At the time of seawater transfer, the average number of fish in each group of the spring and autumn entry fish was 270720 (95\% CI: 171350 to 370090$)$ and 115690 (95\% CI: 53390 to 169 080), respectively. Month of seawater transfer is listed in Table 1. During the seawater period, the fish in this study had been fed with pellets from 4 different feed manufacturers.

The autumn entry fish were slightly larger at vaccination and at sea transfer than the spring entry fish, but of course smaller at the time of sampling because of a shorter growth period and lower seawater temperature (Table 2).

Mean monthly mortality during the seawater period was $0.71 \%$ (95\% CI: 0.48 to $0.94 \%$ ) for the spring entry groups and $1.15 \%$ (95\% CI: 0.51 to $1.79 \%)$ for the 
Table 1. Descriptive statistics on the fish of the 38 spring released groups and the 13 autumn released groups. One spring group was a mix of 2 strains, and is omitted from the table and statistical analysis. Two autumn entry groups and 13 spring entry groups had been fed different feed brands during the seawater period. n: number

\begin{tabular}{|c|c|c|c|c|c|c|c|c|c|}
\hline \multirow[t]{2}{*}{ Variable } & \multirow[t]{2}{*}{ Category } & \multicolumn{4}{|c|}{ Spring entry fish } & \multicolumn{4}{|c|}{ Autumn entry fish } \\
\hline & & $\begin{array}{l}\text { Fish } \\
\text { (n) }\end{array}$ & $\begin{array}{l}\text { Groups } \\
\text { (n) }\end{array}$ & $\begin{array}{c}\text { Mean } \\
\text { cataract-index }\end{array}$ & $95 \%$ CI & $\begin{array}{l}\text { Fish } \\
\text { (n) }\end{array}$ & $\begin{array}{l}\text { Groups } \\
\text { (n) }\end{array}$ & $\begin{array}{c}\text { Mean } \\
\text { cataract-index }\end{array}$ & $95 \%$ CI \\
\hline \multirow[t]{5}{*}{ Fish strain } & $\mathrm{R}$ & 60 & 4 & 2.39 & $2.17-2.61$ & 0 & 0 & & \\
\hline & $\mathrm{S}$ & 346 & 23 & 1.14 & $1.04-1.24$ & 140 & 9 & 0.87 & $0.77-0.97$ \\
\hline & $\mathrm{T}$ & 31 & 2 & 1.10 & $0.81-1.39$ & 15 & 1 & 0.77 & $0.50-1.04$ \\
\hline & $\mathrm{U}$ & 91 & 6 & 1.55 & $1.33-1.77$ & 45 & 3 & 0.81 & $0.63-0.99$ \\
\hline & $\mathrm{V}$ & 33 & 2 & 1.47 & $1.23-1.71$ & 0 & 0 & & \\
\hline \multirow[t]{8}{*}{ County } & Rogaland & 30 & 2 & 1.28 & $0.95-1.61$ & 35 & 2 & 1.19 & $0.95-1.43$ \\
\hline & Hordaland & 76 & 5 & 2.10 & $1.85-2.35$ & 15 & 1 & 0.67 & $0.40-0.98$ \\
\hline & Sogn og Fjordane & 60 & 4 & 1.81 & $1.57-2.05$ & 30 & 2 & 0.63 & $0.43-0.83$ \\
\hline & Møre og Romsdal & 105 & 7 & 1.06 & $0.88-1.24$ & 45 & 3 & 0.84 & $0.64-1.04$ \\
\hline & Sør Trøndelag & 76 & 5 & 0.76 & $0.62-0.90$ & 15 & 1 & 0.57 & $0.33-0.81$ \\
\hline & Nord Trøndelag & 75 & 5 & 1.45 & $1.23-1.67$ & 30 & 2 & 0.92 & $0.74-1.10$ \\
\hline & Nordland & 123 & 8 & 1.28 & $1.12-1.44$ & 15 & 1 & 1.17 & $0.86-1.48$ \\
\hline & Troms & 30 & 2 & 1.22 & $0.93-1.51$ & 15 & 1 & 0.53 & $0.28-0.78$ \\
\hline \multirow[t]{4}{*}{ Feed producer } & A & 137 & 8 & 1.36 & $1.18-1.54$ & 30 & 2 & 1.00 & $0.76-1.24$ \\
\hline & $\mathrm{B}$ & 139 & 9 & 1.87 & $1.69-2.05$ & 45 & 3 & 0.52 & $0.38-0.66$ \\
\hline & $\mathrm{C}$ & 195 & 12 & 1.06 & $0.94-1.18$ & 95 & 6 & 0.96 & $0.82-1.10$ \\
\hline & $\mathrm{D}$ & 104 & 7 & 1.20 & $1.02-1.38$ & 30 & 2 & 0.85 & $0.65-1.05$ \\
\hline \multirow{9}{*}{ Seawater transfer } & March & 30 & 2 & 2.33 & $1.98-2.68$ & 0 & 0 & & \\
\hline & April & 78 & 5 & 1.56 & $1.34-1.78$ & 0 & 0 & & \\
\hline & May & 254 & 17 & 1.29 & $1.17-1.41$ & 0 & 0 & & \\
\hline & June & 181 & 12 & 1.26 & $1.14-1.38$ & 0 & 0 & & \\
\hline & July & 32 & 2 & 0.98 & $0.67-1.29$ & 0 & 0 & & \\
\hline & September & 0 & 0 & & & 90 & 6 & 0.76 & $0.64-0.88$ \\
\hline & October & 0 & 0 & & & 80 & 5 & 1.04 & $0.90-1.18$ \\
\hline & November & 0 & 0 & & & 15 & 1 & 0.47 & $0.22-0.72$ \\
\hline & December & 0 & 0 & & & 15 & 1 & 0.73 & $0.39-0.73$ \\
\hline
\end{tabular}

autumn entry groups. In nearly half $(45 \%)$ of the sea sites clinical infectious pancreatic necrosis had occurred on the fish during the seawater period. Most infectious pancreatic necrosis outbreaks occurred in June and November for the spring entry groups and autumn entry groups, respectively.

Table 2. Weight of sampled groups of Atlantic salmon at the time of vaccination, sea transfer and inspection. n: number

\begin{tabular}{|lccccc|}
\hline Variable & $\begin{array}{c}\text { Groups } \\
(\mathrm{n})\end{array}$ & $\begin{array}{c}\text { Mean weight } \\
(\mathrm{g})\end{array}$ & $95 \% \mathrm{CI}$ & $\begin{array}{c}\text { Min. } \\
\text { value }(\mathrm{g})\end{array}$ & $\begin{array}{c}\text { Max. } \\
\text { value }(\mathrm{g})\end{array}$ \\
\hline $\begin{array}{l}\text { Weight at vaccination } \\
\text { Spring entry }\end{array}$ & 38 & 57 & $50-64$ & 25 & 115 \\
$\begin{array}{l}\text { Autumn entry } \\
\text { Total }\end{array}$ & 13 & 64 & $44-84$ & 34.5 & 140 \\
Weight at sea transfer & 51 & 58 & $51-65$ & 25 & 140 \\
Spring entry & 38 & 80 & $72-88$ & 45 & 143 \\
$\begin{array}{l}\text { Autumn entry } \\
\text { Total }\end{array}$ & 13 & 108 & $79-137$ & 50 & 200 \\
Weight at inspection & 51 & 86 & $76-96$ & 45 & 200 \\
$\begin{array}{l}\text { Spring entry } \\
\text { Autumn entry }\end{array}$ & 38 & 2908 & $2604-3212$ & 1320 & 5319 \\
Total & 13 & 1206 & $825-1587$ & 464 & 2327 \\
& 51 & 2474 & $2155-2793$ & 464 & 5319 \\
\hline
\end{tabular}

\section{Clinical findings}

Spring entry fish had more frequent and severe clinical findings in the eyes than the autumn entry fish (Fig. 2). The mean cataract index was 1.36 (95\% CI: 1.28 to 1.44$)$ for the spring entry fish and 0.85 (95\% CI: 0.76 to 0.94 ) for the autumn entry fish, the difference being statistically significant $(\mathrm{p}<0.05)$.

The prevalence of all visible cataracts in spring entry fish and autumn entry fish was 83 and $79 \%$, respectively. The within-site prevalence of cataracts varied between 40 and $100 \%$. In $12(40 \%)$ of the spring entry groups, all the fish sampled were affected with some degree of cataract formation. Altogether $30 \%$ of the fish, $9 \%$ of the autumn entry fish and $37 \%$ of the spring entry fish had score 2 or higher on both eyes and $5 \%$ of the fish were scored 3 or 4 ; all of these were spring entry fish. Unilateral cataracts were found more fre- 


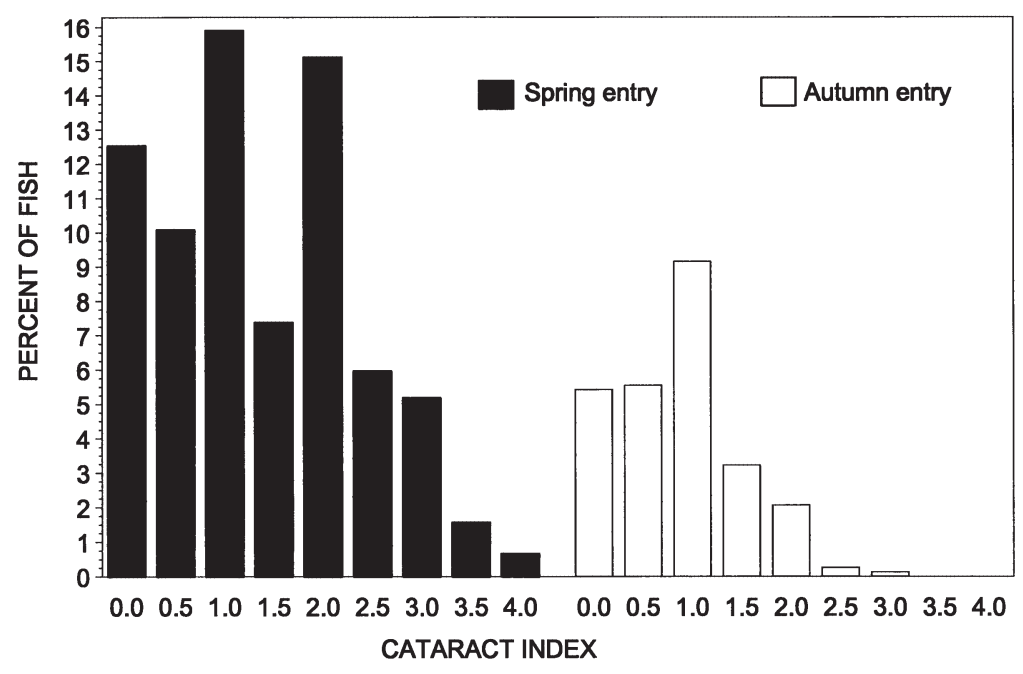

Fig. 2. Relative frequency distribution of the cataract index within the spring and autumn entry groups of farmed Atlantic salmon

The prevalence and severity of cataracts differed between sites in different counties. The average cataract index was highest for fish from Hordaland and Sogn og Fjordane and the lowest in Sør Trøndelag, Nordland and Troms (Table 4). The random effect of sea site contributed a variance component ratio of 0.27 relative to the error term in the final mixed model.

No significant association was found between the dependent variable cataract index and the independent variables for autumn entry groups.

\section{Weight at inspection and cataract index}

For both populations a negative association was found between the cataract index and the weight of the fish, both determined at the day of examination

quently in autumn entry fish (31\%) than spring entry fish $(23 \%)$. The majority of the fish with unilateral cataracts had minor changes (score 1) in the affected eye.

The mean group-level cataract index for spring and autumn entry groups was estimated to be 1.36 (95\% CI: 1.13 to 1.59 ) and 0.83 (95\% CI: 0.66 to 1.00$)$, respectively. The variation within the autumn entry fish was not as large as the cataract index at pen level, varying from a minimum of 0.47 to a maximum of 1.50 (Table 3), while the corresponding values for the spring entry fish were 0.29 and 3.10 .

\section{Association between explanatory variables and cataracts}

For spring entry groups, 3 explanatory variables were included in our final model with the cataract index as the outcome: weight at sea transfer, strain and county (Table 4). Generally, the fish groups with higher weight at sea transfer also had a significantly higher cataract index at the time of sampling. Fish with an average weight of less than $64 \mathrm{~g}$ at the time of seawater transfer had a mean cataract index of 1.22, while the fish groups weighing more than $87 \mathrm{~g}$ scored on average 1.80 .

Significant differences in cataract formation were observed between the offspring of some of the 5 Norwegian salmon strains represented in the sample of spring groups, with an adjusted mean cataract index of the poorest and the best strain being 2.39 (95\% CI: 2.13 to 2.70 ) and 0.51 (95\% CI: 0.14 to 0.96 ), respectively (Table 4).
(Fig. 3). The average weight of the fish with the highest cataract score among the spring entry groups was estimated to be $981.6 \mathrm{~g}$, compared with a mean of $3093.4 \mathrm{~g}$ for fish without visible cataracts.

A significant negative correlation was observed between SGR and the cataract index in the spring entry (Pearson's $r=-0.17, \mathrm{p}<0.0001$ ). In the autumn entry fish the corresponding estimate was negative but non-significant $(r=-0.10, \mathrm{p}<0.16)$.

\section{DISCUSSION}

In the present study, some degree of cataract formation was found in all the investigated fish groups, and the estimated overall prevalence of lens opacities was about $82 \%$. The prevalence level is coincident with the findings of Bjerkås et al. (1996). According to Wall \&

Table 3. Cataract index for all the groups and at the spring and autumn entry groups level

\begin{tabular}{|lcccc|}
\hline Variable & $\begin{array}{c}\text { Mean cataract } \\
\text { index }\end{array}$ & $95 \%$ CI & $\begin{array}{c}\text { Min. } \\
\text { value }\end{array}$ & $\begin{array}{c}\text { Max. } \\
\text { value }\end{array}$ \\
\hline Spring entry & 1.36 & $1.28-1.44$ & 0 & 4 \\
$\begin{array}{l}\text { Fish level } \\
\text { Group level }\end{array}$ & 1.36 & $1.13-1.59$ & 0.29 & 3.10 \\
$\begin{array}{l}\text { Autumn entry } \\
\text { Fish level }\end{array}$ & 0.85 & $0.76-0.94$ & 0 & 3 \\
Group level & 0.83 & $0.66-1.00$ & 0.47 & 1.50 \\
Total & 1.22 & $1.15-1.29$ & 0 & 4 \\
$\begin{array}{l}\text { Fish level } \\
\text { Group level }\end{array}$ & 1.23 & $1.05-1.41$ & 0.29 & 3.10 \\
\hline
\end{tabular}


Table 4. The results from the final multivariate model of the cataract index as the outcome in the field study of Norwegian sea farmed Atlantic salmon groups transferred to sea in the spring and early summer of 1997. n: number

\begin{tabular}{|c|c|c|c|c|c|}
\hline Variable & Category & $\begin{array}{l}\text { Groups } \\
\text { (n) }\end{array}$ & $\begin{array}{l}\text { Fish } \\
\text { (n) }\end{array}$ & $\begin{array}{l}\text { Least square mean } \\
\qquad(95 \% \mathrm{CI})\end{array}$ & $\begin{array}{l}\mathrm{p} \text {-value for } \\
\text { the variable }\end{array}$ \\
\hline \multirow[t]{3}{*}{ Weight (g) } & $\leq 64$ & 12 & 182 & $1.22(1.02-1.41)$ & \multirow[t]{3}{*}{$<0.01$} \\
\hline & $65-86$ & 13 & 197 & $1.33(1.17-1.49)$ & \\
\hline & $\geq 87$ & 12 & 182 & $1.80(1.61-1.99)$ & \\
\hline \multirow[t]{8}{*}{ County } & Rogaland & 2 & 30 & $1.22(0.87-1.57)$ & \multirow[t]{8}{*}{$<0.01$} \\
\hline & Hordaland & 5 & 76 & $1.99(1.74-2.24)$ & \\
\hline & Sogn og Fjordane & 4 & 46 & $2.30(1.96-2.64)$ & \\
\hline & Møre og Romsdal & 7 & 105 & $1.20(0.95-1.46)$ & \\
\hline & Sør-Trøndelag & 5 & 76 & $0.88(0.61-1.14)$ & \\
\hline & Nord-Trøndelag & 5 & 75 & $1.75(1.50-1.99)$ & \\
\hline & Nordland & 8 & 123 & $1.05(0.88-1.22)$ & \\
\hline & Troms & 2 & 30 & $1.21(0.88-1.55)$ & \\
\hline \multirow[t]{5}{*}{ Fish strain } & $\mathrm{T}$ & 2 & 31 & $0.51(0.14-0.96)$ & \multirow[t]{5}{*}{$<0.001$} \\
\hline & $\mathrm{R}$ & 4 & 60 & $2.39(2.13-2.7)$ & \\
\hline & $\mathrm{U}$ & 6 & 91 & $0.98(0.7-1.23)$ & \\
\hline & $\mathrm{V}$ & 2 & 33 & $1.99(1.61-2.4)$ & \\
\hline & $\mathrm{S}$ & 23 & 346 & $1.39(1.3-1.5)$ & \\
\hline
\end{tabular}

Bjerkås (1999), scores 2 and 3 in the scoring system are given when the opacity covers 10 to 50 and 50 to $75 \%$ of the lens area, respectively. Consequently, we believe that for nearly $30 \%$ of the fish that were given cataract score 2 or higher on both eyes the vision was impaired and that approximately $5 \%$ of the fish were effectively blind in 1 or both eyes. Seventy-five percent of the affected fish had bilateral cataracts, and the majority of those with unilateral cataracts had only minor changes in the affected eye. That the majority had bilateral cataracts indicates that the cause of the disorder is systemic, a hypothesis that is also supported by Bjerkås et al. (1996).

The prevalence and severity of findings varied considerably among sampling sites, but the overall prevalence of cataracts found in the current study is close to the maximum prevalence observed in Irish, Scottish and Norwegian fish farms by Wall (1998). His study covered smolts transferred to sea in 1996, and the agreements in the results in our studies confirm the severity of the cataract problem in salmon aquaculture.

In the present study, the severity of cataracts observed in autumn entry smolts was significantly less than in the spring transferred fish. This is contradictory to clinical observations from Ireland and Scotland in 1995-1996 (Wall 1998), where the autumn entry fish were more affected. The autumn entry fish of the current study were mostly $\mathrm{S} 1 / 2$ and thus most certainly of a different genetic pool from the spring entry group. Further, they had not been exposed to the high seawater temperatures during the late summer of 1997 and had therefore undergone a different growth pat-

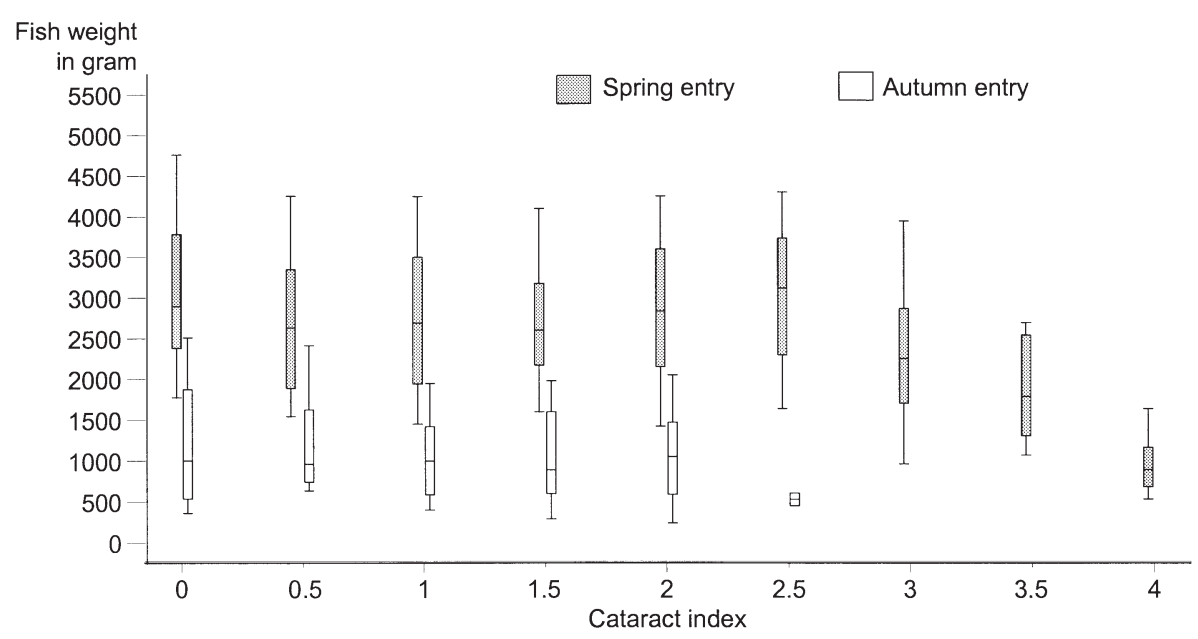

Fig. 3. Box-and-whiskers plots of individual fish weight related to the cataract index at the time of investigation for the spring and autumn entry groups of seawater farmed Atlantic salmon 
tern. The results from the statistical analyses of data from autumn entry fish generally supported those from the spring entry sample, albeit statistically non-significant, due to a small sample size. The apparent discordance with Wall's (1998) results may be explained by undiscovered differences in the genetic properties and management of various populations studied.

In the present study it was shown that the risk for cataract development was significantly related to the heredity of the fish, an observation that supports the alleged importance of this factor (Wall 1998). The strains included in the present study have been subject to selective breeding based predominantly on growth rate, a trait that may be coupled to metabolic capacities of particular importance for lens development and growth. Whether the increased risk is directly related to genetic constitution or an indirect effect of genetically determined differences in growth patterns cannot be clarified by this study.

The summer of 1997 was hot and sunny with seawater temperatures above normal, especially in south Norway. Data from the Norwegian Meteorological Institute showed that the mean seawater temperature in August measured at Slåtterøy lighthouse in Hordaland county was $5^{\circ} \mathrm{C}$ above the normal mean temperatures for this month. In the current data, there was a marked gradient in summer water temperatures from south to north. Replacing the variable 'county' by the average water temperature of August 1997 as measured at 1 of the lighthouses located in the county in the statistical analysis gave corresponding results; however, the model fitness was poorer than for the final model. We therefore believe that climatic conditions are among the dominant features of the geographic risk factor identified in this study.

The third significant risk factor for cataract development was high average weight when transferred to sea, coinciding with early sea transfer and with a longer time in seawater before investigation. During a normal freshwater production cycle, groups of large smolts fit for early sea transfer are formed through periodic grading. Early transferred groups consequently comprise a selection of those individuals showing the fastest growth in fresh water. Our findings therefore support the conclusions of Bjerkås et al. (1996) and Waagbø et al. (1996) regarding the association between cataract development and fast growth. The development of cataracts may be progressive in nature and early transferred groups were obviously at risk over a prolonged period of time, explaining the observed association between cataract index and time at sea.

In contrast to Wall (1998) we found no significant association between the prevalence or the severity of cataracts and specific feed brands. Differences in cataract index of groups fed various brands were evident when the relation was analysed separately, but when adjusted for the covariation with geographic location and smolt strain through the multivariate analysis, the effect of feed brand became non-significant. Several farmers used several feed brands and all of them had changed brands, formula or pellet size during the sea rearing period of the population under study. Therefore, the feeding information was not deemed sufficiently reliable to warrant further statistical analyses. The increment in the incidence of cataracts in seawater farmed salmon in Ireland, Scotland and Norway has been linked to the withdrawal of blood meal from the feed (Wall 1998). The eye lens is vulnerable as it has no blood supply of its own, and as a consequence is dependent on supply of nutrients from the anterior chamber fluid or aqueous humour. Fish eyes grow rapidly in juvenile life (Johns 1981) and the metabolic activity in the fish lens is high (Wei \& Augusteyn 1994). Bjerkås et al. (1996) found that cataracts originate in the anterior lens pole and later in the posterior cortex. The outer cortical layers are the areas with the highest metabolic activity in the lens (Wei \& Augusteyn 1994). During rapid growth a relative lack of some essential nutrients may therefore affect the development of the lens. Other possibilities are that the capacity of the enzyme systems in the lens is exhausted during fast growing periods or that the lens epithelium is not capable of using the nutrient supplies for production of correctly conformed lens proteins.

Some of the consequences of cataract development are indicated through our analysis of factors associated with reduced fish weight at the time of investigation. As can be seen in Fig. 3, the threshold to lower weight of individual fish is at a cataract index of 2.5, which affected nearly $14 \%$ of the fish in the current study. We believe that the reduced weight observed in the present study is a function of decreased feed intake because of visual impairment. This is also a likely explanation for the marked negative correlation between the SGR and average cataract index of the spring entry groups in this study. The SGR in this case is the average growth over a long period, indicating that irreversible cataracts pose not only a temporal, but also a long-term or even continuous influence on growth of the fish for the rest of the production cycle.

A representative selection of sea sites was attempted in the present study and, compared with the reference population, a fair representation of the main farming regions was reached. The county Hordaland, however, which is Norway's largest in tonnage produced, was underrepresented, whereas the county Møre \& Romsdal was overrepresented in the study sample. According to the regional differences in cataract develop- 
ment, our estimate on cataract prevalence and severity in Norway as a whole may be conservative. A potential bias in the opposite direction was associated with the netting of sample fish out of large pens. Blind fish tend to swim near the surface in the cage and their actions are slower, making them easier to catch. The use of feed to attract fish to the surface to catch them by hand net might, however, favour the selection of wellsighted individuals. The fish in the present study were investigated on-site as rapidly as possible after death to avoid osmotic lens changes, which can produce false positive results. The clinical findings during the investigations did not suggest that this posed a problem.

In conclusion, the present study has shown an unacceptably high prevalence of cataracts in farmed Atlantic salmon in Norway. The high prevalence raises questions concerning fish health and welfare and is a challenge for the industry. The results suggest that causative factors for cataract development in farmed salmon are of a systemic nature and associated with rapid growth. Studies of different design are, however, required to identify specific nutritional imbalance or metabolic bottlenecks leading to cataract development, to discriminate between secondary (growth rate mediated) and direct genetic risk factors, and to identify direct from indirect (growth rate mediated) effects of water temperature.

Acknowledgements. Thanks to all the veterinarians and the fish farmers who attended and organised in the field, Ellen Bjerkås for her helpful training in lens evaluation and clinical advise, and Conrad Helgeland for his field assistance. The study was funded by The National Veterinary Institute, The Norwegian Fish feed producers Association, Hydro Seafood AS and VESO Vaccines.

\section{LITERATURE CITED}

Barash H, Poston HA, Rumsey GL (1982) Differentiation of soluble proteins in cataracts caused by deficiencies of methionine, riboflavin or zinc in diets fed to Atlantic salmon, Salmo salar, rainbow trout, Salmo gairdneri, and lake trout, Salvelinus namaycush. Cornell Vet 72:361-371

Benedek GB (1997). Cataract as a protein condensation disease. (The Proctor Lecture). Invest Ophthalmol Vision Sci 38:1911-1921

Bjerkås E, Bjørnestad E (1999) Is there a connection between rapid fluctuation in water temperature and cataract development in the Atlantic salmon (Salmo salar L.). Bull Eur Assoc Fish Pathol 19:166-169

Bjerkås E, Waagbø R, Sveier H, Breck O, Bjerkås I, Bjørnestad E, Maage A (1996) Cataract development in Atlantic salmon (Salmo salar L) in fresh water. Acta Vet Scand 37: 351-360

Bruno DW, Raynard RS (1994) The effect of water temperature on eye opacity in Atlantic salmon, Salmo salar, L. Bull Eur Assoc Fish Pathol 14:86-88

Editorial responsibility: Carl Schreck,

Corvallis, Oregon, USA
Cowey CB, Cho CY, Sivak JG, Weerheim JA, Stuart DD (1992) Methionine intake in rainbow trout (Oncorhynchus mykiss), relationship to cataract formation and the metabolism of methionine. J Nutr 122:1154-1163

Cullen AP, Monteith-McMaster CA (1993) Damage to the rainbow trout (Oncorynchus mykiss) lens following an acute dose of UVB. Curr Eye Res 12:97-106

Fraser PJ, Duncan G, Tomlinson J (1989) Effects of a cholinesterase inhibitor of salmonid lens: a possible cause for the increased incidence of cataract in salmon Salmo salar (L.). Exp Eye Res 49:293-298

Hargis WJ Jr (1991) Disorders of the eye in finfish. Annu Rev Fish Dis 1:95-117

Hughes SG (1985) Nutritional eye diseases in salmonids: a review. Prog Fish-Cult 47:81-85

Hughes SG, Riis RC, Nickum JG, Rumsey GL (1981) Biomicroscopic and histologic pathology of the eye in riboflavin deficient rainbow trout (Salmo gairdneri). Cornell Vet 71: 269-279

Iwata M, Komatsu S, Collie NI, Nishioka RS, Bern HA (1987). Ocular cataracts and seawater adaption in salmonids. Aquaculture 66:315-327

Johns P (1981) Growth of fish retinas. Am Zool 21:447-458

Ketola HG (1979) Influence of dietary zinc on cataracts in rainbow trout. J Nutr 109:965-969

Kincaid HL, Elrod JH (1991) Growth and survival of stocked lake trout with nuclear cataracts in Lake Ontario. N Am J Fish Manage 11:429-434

Loewenstein MA, Bettelheim FA (1979) Cold cataract formation in fish lenses. Exp Eye Res 28:651-663

Page JW (1978) Nutritionally induced cataracts in rainbow trout. Symposium on the Comparative Pathology of Zoo Animals, Smithsonian Institution, p 99-105

Phelps Brown N, Bron AJ (1996). Lens disorders. A clinical manual of cataract diagnosis. Butterworth Heinemann, Oxford

Poston HA, Rumsey GL (1983) Factors affecting dietary requirement and deficiency signs of L-tryptophan in rainbow trout. J Nutr 113:2568-2577

Poston HA, Riis RC, Rumsey GL, Ketola HG (1977) The effect of supplemental dietary amino acids, minerals and vitamins on salmonids fed cataractogenic diets. Cornell Vet 67:472-509

Richardson NL, Higgs DA, Beames RM, McBride JR (1985) Influence of dietary calcium, phosphorous, zinc and phytate level on cataract incidence, growth and histopathology in juvenile chinook salmon (Oncorhynchus tshawytscha). J Nutr 115:553-567

Waagbø R, Bjerkås E, Sveier H, Breck O, Bjørnestad E, Maage A (1996) Nutritional status assessed in groups of smolting Atlantic salmon, Salmo salar L., developing cataracts. J Fish Dis 19:365-373

Wall AE (1998) Cataracts in farmed Atlantic salmon (Salmo salar) in Ireland, Norway and Scotland from 1995-1997. Vet Rec 142:626-631

Wall AE, Richards RH (1992) Occurrence of cataracts in triploid Atlantic salmon (Salmo salar) on four farms in Scotland. Vet Rec 131:553-557

Wall T, Bjerkås E (1999) A simplified method of scoring cataracts in fish. Bull Eur Assoc Fish Pathol 19:162-165

Walton MJ, Cowey CB, Adron JW (1982) Methionine metabolism in rainbow trout fed diets of differing methionine and cysteine content. J Nutr 112:1525-1535

Wei ZZ, Augusteyn RC (1994) Ageing of glutathione reductase in the lens. Exp Eye Res 59:91-96

Submitted: June 8, 2000; Accepted: April 6, 2001

Proofs received from author(s): July 17, 2001 